УДК 378.015.32:[316.362:159.8

DOI https://doi.org/10.32838/2709-3093/2021.2/16

\title{
Панченко В.О.
}

Національний університет «Чернігівський колегіум»

імені Т.Г. Шевченка

\section{ПСИХОЛОГІЧНІ ОСОБЛИВОСТІ ШЛЮБНО-СІМЕЙНИХ УСТАНОВОК СТУДЕНТСЬКОЇ МОЛОДІ}

У статті обтрунтовано актуальність дослідження шлюбно-сімейних установок та їх особливостей у студентської молоді.

Здійснено експериментальне дослідження шлюбно-сімейних установок студентської молоді трьох груп із різною сферою навчальної діяльності: психологів, музикантів та істориків. Вектор дослідження спрямовано на вивчення гендерних установок та гендерних ставлень особистості, уточнення уявлень подружжя про значущість у сімейному житті сексуальних стосунків, особистісну спільність чоловіка та дружини, батьківські обов'язки, професійні інтереси кожного з подружжя, господарсько-побутовий аспект відносин, моральну та емоційну підтримку, зовнішню привабливість партнера, визначення установок подружжя щздо найбільш значущих у сімейній взаємодї сфер людського життя та для вивчення ступеня сочіально-психологічної сумісності шлюбних партнерів.

Визначено психологічні особливості шлюбно-сімейних установок студентської молоді. Представники усіх груп надають перевагу установкам опори, тяжіння та незалежності. Студенти-психологи в майбутньому очікують від свого илюбного партнера активної батьківської позииї; хочуть «бути психологом» у власній сім '̈̈ (ие пояснюється специфікою ӥхньої освіти), відчувати емочійну підтримку від партнера, бажають пов'язати життя з зовнішньо привабливою особистістю, лояльно ставляться до розлучень. Студенти-музиканти мають високі показники за шкалою особистісної ідентифікаиії, прагнуть до задоволення власних професійних потреб, прагнуть бачити у партнері емоційного лідера, мають значиму установку на власну привабливість, потребують реалізаиї себе у професійній сфері, не надають значення господарсько-побутовим проблемам. Особливість установок студентів-істориків полягає в такому: бажсання надати права емоційного лідера власному партнеру при одночасному прагненні самому виконувати роль сімейного психотерапевта; неважливість зовнішньої привабливості партнера по шлюбу; занижені потреби інтимно-сексуальних рольових очікувань; значне прагнення до спільної діяльності; негативне ставлення до розлучень.

Окреслено перспективи подальших наукових розвідок у межах зазначеної теми.

Ключові слова: сім'я, илюб, илюбно-сімейні установки, гендерні установки, очікування та домагання у шлюбі, студентська молодь.

Постановка проблеми. Сім'я в усі часи була та залишається однією $з$ найважливіших цінностей для людини. Родина робить життя кожного щасливим, повноцінним та плідним. Сучасні вчені визначають сім'ю як справжню школу людських взаємовідносин, в якій людина росте, розвивається і вдосконалюється. Залежно від часу, особливостей та змін у суспільстві вона, як і будь-яке інше соціальне утворення, піддається впливам, змінюється, розвивається. У сучасному світі змінюється і ставлення до цього важливого соціального інституту, в розвитку шлюбних взаємовідносин настають зміни та відбуваються трансформації. Проблеми, що виникають у сімейних стосунках, знаходження порозуміння 3 сімейним партнером, розвиток сім’ї та окремої особистості можуть пояснюватись соціальнопсихологічними установками на сімейне життя, сформованими ще задовго до шлюбу. Будучи невід'ємним атрибутом життя людини, ці установки відіграють велику роль у формуванні ставлення до сімейного життя та $є$ фундаментом у виборі моделі сімейних відносин для побудови своєї майбутньої сім’ї. У психологічній науці існує проблема готовності до створення сім’ї, яка набула найбільшої гостроти протягом останніх кількох десятиліть. 3 огляду на це існує необхідність дослідити механізми формування сімейних стосунків. Одним із таких механізмів $€$ шлюбносімейна установка. Незважаючи на збільшений інтерес у психологічній науці до цісї теми, деякі їі аспекти потребують додаткового вивчення. 
Аналіз останніх досліджень та публікацій. Проблему шлюбу, психологічної готовності до шлюбу та шлюбно-сімейних установок досліджували А.Р. Харчев, А.І. Антонов, З.Г. Кісарчук, Ф.А. Брокгауз, I.А. Ефрон, С. Голод, Е. Гілденс, В. Сисенко (дослідження феномена шлюбу в психології), В. Торохтій, М. Земська, І.Г. Гребенніков (псіхологічна готовність до шлюбу), С. Кратохвіл, А. Петровський, С. Ковальов, А.К. Лук'янов, О.І. Болдирєва, I.О. Торкунова, М.В. Петровська, А.А. Емільяненко та ін. (проблема шлюбно-сімейних установок).

Постановка завдання. Метою нашого дослідження $€$ визначення психологічних особливостей шлюбно-сімейних установок студентської молоді.

Виклад основного матеріалу дослідження. Щоб дослідити психологічні особливості шлюбносімейних установок студентської молоді, опитуванням були охоплені здобувачі освіти різних напрямів професійної підготовки. У дослідженні взяли участь 118 осіб: 39 студентів психолого-педагогічного факультету НУ «Чернігівський колегіум» імені Т.Г. Шевченка (психологи), 36 та «співробітництво», не набрали жодного вибору. Випробовувані мають низьку статево-рольову диференціацію, їм не властиве розуміння типового чоловічого та типового жіночого. Ймовірно, що ні кар'єра, ні соціальний статус не $є$ важливими життєвими цінностями у представників усіх трьох груп.

Зважаючи на вищевикладене, можемо констатувати подібність результатів психологів та музикантів, адже більшість їхніх гендерних установок схожі.

Далі аналізуємо особливості рольових очікувань та домагань у шлюбі (за результатами методики «Рольові очікування та домагання у шлюбі» А.Н. Волкової).

Показник низького рівня інтимно-сексуальних рольових очікувань виявився у представників трьох груп у такому відсотковому співвідношенні: історики - 32\%, психологи - 16\%, музиканти - лише 5\%. Студенти-історики більше, ніж інші, недооцінюють сексуальні стосунки у шлюбі. Ймовірно, секс для них є елементом, який лише супроводжує стосунки, і є технічною, процесуальною стороною. У музикантів та психологів більшою мірою розвинена емоційно-чуттєва сфера, чим і пояснюються значні вибори в плані сексуального аспекту сімейного життя. I сексу вони надають більшу перевагу, ніж історики.

Порівнявши показники високого рівня особистісної ідентифікації, констатуємо результати: $40 \%$ музикантів, $32 \%$ психологів та $28 \%$ істориків мають високі показники за цією шкалою. Музиканти очікують від власного партнера спільності в інтересах, потребах, ціннісних орієнтаціях, способах проведення дозвілля. Можемо припустити, що такі результати зумовлені тим, що творчі люди найчастіше потребують партнерів, собі подібних, адже 3 ними легше буде знайти спільну мову, спільні теми для розмови, спільні інтереси.

Щодо господарсько-побутових очікувань, то музиканти меншою мірою ( $25 \%$ низького рівня), ніж психологи та історики (по 4\% низькогорівня) схильні висувати побутові вимоги до шлюбних партнерів та делегувати їм частину домашньої роботи. Можливо, вони бачать спільне життя з рівним розподілом побутових питань. Серед психологів (48\% високого рівня) та істориків (36\% високого рівня) спостерігається значна частина таких, хто прагне до власного ведення домашнього господарства.

У виконанні батьківсько-виховної функції простежується таке: психологи (72\% високого рівня) більше, ніж музиканти (40\% високого рівня) та історики (36\% високого рівня) орієнтовані на власні обов'язки у вихованні дітей. Можливо, така думка посилюється специфікою освіти студентів психологічного напряму, що забезпечує їх знаннями про тонкощі виховання та особливості психологічного розвитку майбутньої дитини. Разом із цим перевага психологів спостерігається і в орієнтації на спільну діяльність із партнером.

Показник соціальної активності (високий рівень) виокремлює психологів (52\%) та істориків (48\%) від музикантів (30\%). Студенти психологічного та історичного напрямів мають більш виражену установку на значущість зовнішньої соціальної активності для стабілізації шлюбно-сімейних стосунків. Музиканти показують менш чіткі уявлення про професійні потреби власного майбутнього шлюбного партнера. Поряд із цим психологи (72\% високого рівня) демонструють вираженість професійних потреб дружини/чоловіка.

Отримані результати за емоційно-психотерапевтичною шкалою знову ж виокремлюють психологів за високим показником (73\%) від музикантів (35\%) та істориків (33\%). Такий високий показник є свідченням очікувань студентів-психологів, спрямованих на те, що шлюбний партнер візьме на себе роль емоційного лідера в сім’і у вирішенні питань корекції психологічного клімату, наданні моральної та емоційної підтримки, створенні психотерапевтичної атмосфери. А от історики (70\% високого рівня за шкалою емоційно-терапевтичних домагань) прагнуть бути сімейними психотерапевтами для свого партнера. 
Показники високого рівня за шкалою зовнішньої привабливості (очікування) засвідчує, що для психологів (68\%) зовнішній вигляд майбутнього шлюбного партнера має більше значення, ніж для музикантів (30\%) та істориків (32\%). Музиканти (60\% високого рівня за шкалою зовнішньої привабливості (домагання)) демонструють установку на власну привабливість, прагнення гарно виглядати.

Аналізуючи особливості установок у сімейній парі (за опитувальником Ю.С. Альохіної), можемо звернути увагу на їх особливості. Історики (43\%), на відміну від психологів (16\%) та музикантів $(20 \%)$, значно більше виявляють позитивне ставлення до людей, що видається нам парадоксальним, адже і психологи, і музиканти в професії безпосередньо спілкуються з людьми. Психологи (35\%) та музиканти (37\%) більшою мірою, ніж історики (12\%) схильні до захоплення і водночас не надають значення виконанню родинних обов'язків. А от за шкалою ставлення до дітей історики є лідерами серед трьох груп із високим показником у $46 \%$.

Показники шкали спільної/розділеної діяльності доводять значне прагнення істориків (42\%) та психологів (53\%) до спільної діяльності. Ймовірно, музиканти вбачають у своїй половині музу, що не спонукає їх спільно діяти. Також історики $(32 \%)$ і психологи (28\%) негативно ставляться до розлучення, музиканти (12\%), навпаки, лояльно сприймають розрив.

Показники ставлення до кохання вирізняють психологів (11\%) 3-поміж двох інших груп (по $32 \%$ ). Можливо, особливості професії, а саме знання і розуміння причин сімейних проблем, емоційне вигоряння знижують романтичність у стосунках із партнером. Аналізуючи шкалу ставлення до грошей, ми виявили більш заощадливе ставлення до них у психологів (54\%) та істориків (43\%). Музиканти (10\%) зовсім не схильні до заощаджень, що ще раз доводить творчість та нематеріальність їх натури.

На наступному етапі дослідження нам було цікаво проаналізувати взаємозв'язки (за критерієм Спірмена) між шлюбно-сімейними установками усередині кожної з груп. Результати цього аналізу нині і представляємо.

У групі студентів психологів виявлені наведені нижче кореляції. Господарсько-побутова установка (домагання) взаємопов'язана з установкою на кохання $(\mathrm{r}=-341$; при $\mathrm{p}<0,01)$. Ймовірно, господарство забирає багато часу і кохання від цього страждає. Господарсько-побутова установка корелює зі ставленням до грошей $(\mathrm{r}=432$; при $\mathrm{p}<0,05)$ : чим сильнішою $є$ установка на вирішення побутових питань, тим більш матеріально заощадливішим є партнер. Батьківсько-виховна установка (очікування) обернено корелює з установкою на кохання ( $r=-421$; при $\mathrm{p}<0,01)$. Можливо, i турбота про дітей та виконання батьківської функції теж не дає психологам повністю реалізуватися в коханні. Інтимно-сексуальна установка взаємопов'язана зі сферою сексу $(r=632$; при $\mathrm{p}<0,05)$. Сексуальна гармонія безпосередньо залежить від наявності сексуальної сфери. Сфера сексу також пов'язана з соціальною активністю психологів ( $\mathrm{r}=387$; при $\mathrm{p}<0,01)$.

У групі музикантів теж виявилися цікаві кореляції між установками. Батьківсько-виховна установка (очікування) взаємопов'язана з установкою обов'язку-задоволення ( $\mathrm{r}=-490$; при $\mathrm{p}<0,05)$, що може пояснювати перевагу активної батьківської позиції над задоволеннями в стосунках і навпаки. Установка соціальної активності (домагання) обернено корелює зі ставленням до дітей $(\mathrm{r}=-417$; при $\mathrm{p}<0,05)$, що доводить неможливість музикантів займатись одночасно і кар'єрою, і вихованням дітей. Установка особистісної ідентифікації взаємопов'язана 3 установкою ставлення до розлучення $(\mathrm{r}=-396$; при $\mathrm{p}<0,05)$, що є свідченням того, що спільні інтереси, потреби, ціннісні орієнтації, спільне проведення часу подружжям ведуть до поліпшення відносин та розуміння і підтримки, а не навпаки. Так само, як і в психологів, у групі музикантів виявлено кореляцію інтимно-сексуальної установки зі сферою сексу $(\mathrm{r}=518$; при $\mathrm{p}<0,01)$. Установка спільної/розділеної діяльності взаємопов'язана 3 батьківсько-виховною установкою (домагання) $(\mathrm{r}=453$; при $\mathrm{p}<0,05)$. Спільна діяльність подружжя в усіх сферах сімейного життя дає поштовх музикантові до розуміння важливості родини у його житті, стимулює бажання бути хорошим батьком (матір'ю) та відповідально ставитись до виховання майбутніх дітей.

Щодо істориків, то в цій групі теж виявились значимі взаємозв'язки. Емоційно-психотерапевтична установка обернено корелює з установкою ставлення до людей $(\mathrm{r}=-510$; при $\mathrm{p}<0,01)$. Досліджувані цього навчального напряму прагнуть бути для свого майбутнього партнера сімейним терапевтом, намагаються залагодити конфлікти та непорозуміння в родині. Взаємозв'язок господарсько-побутової установки з установкою ставлення до дітей $(\mathrm{r}=-445$; при $\mathrm{p}<0,05)$ доводить, що історики не зможуть одночасно займатися побутом i належно виховувати дитину. Господарсько-побутова установка (домагання) так само обернено корелює і з установкою ставлення до кохання, 
доводячи, що історик, який багато часу відводить на господарство, не в змозі приділяти увагу партнерові i, навпаки, активні романтичні стосунки унеможливлюють якісне ведення господарства. А от кореляція батьківсько-виховної установки 3 установкою ставлення до кохання $(\mathrm{r}=495$; при $\mathrm{p}<0,05)$ демонструє, що можна одночасно займатись вихованням дітей і не втрачати романтики 3 партнером. Емоційно-психотерапевтична установка (очікування) в істориків взаємопов'язана 3 установкою ставлення до кохання ( $\mathrm{r}=-510$; при $\mathrm{p}<0,01)$, що, ймовірно, доводить: якщо чоловік/ дружина хоче перебувати в ролі домашнього психотерапевта, це розглядається партнером як повчання і відштовхує подружжя одне від одного. Кореляція виявлена і між установками соціальної активності та сферою сексу ( $\mathrm{r}=-510$; при $\mathrm{p}<0,01)$. Логічним, на наш погляд, є взаємозв'язок установки зовнішньої привабливості(домагання) 3 установкою заборони сексу ( $\mathrm{r}=-449$; при $\mathrm{p}<0,01)$ : чим привабливішою людина себе відчуває, тим більша вірогідність того, що в неї зникають усі внутрішні сексуальні заборони. А от установка заборони сексу (очікування) обернено корелює теж з установкою зовнішньої привабливості, що $\epsilon$ свідченням сором'язливості та відчуття дискомфорту у сфері сексу істориків, які вважають себе непривабливими. Господарсько-побутова установка (очікування) має зв'язок з установкою патріархальної/егалітарної структури родини ( $\mathrm{r}=-462$; при $\mathrm{p}<0,05)$, що свідчить про ймовірну допомогу в господарських питаннях партнерові за умови його активної батьківської позиції, орієнтування та виконання власних обов'язків щодо виховання дітей, традиційного розуміння ролі жінки/чоловіка в сім’ї.
Висновки. Зважаючи на вищезазначене, можемо стверджувати про особливості установок студентів. Представники усіх груп надають перевагу установкам опори, тяжіння та незалежності. Студенти-психологи очікують від свого шлюбного партнера активної батьківської позиції, хочуть «бути психологом» у власній сім’ї, що пояснюється специфікою їхньої освіти, прагнуть відчувати емоційну підтримку від партнера, бажають пов'язати життя 3 зовнішньо привабливою особистістю, лояльно ставляться до розлучень. Студенти-музиканти мають високі показники за шкалою особистісної ідентифікації, прагнуть до задоволення власних професійних потреб, прагнуть бачити у партнері емоційного лідера, мають значиму установку на власну привабливість, потребують реалізації себе у професійній сфері, не надають значення господарсько-побутовим проблемам. Особливість установок студентівісториків полягає в бажанні надати права емоційного лідера власному партнеру при одночасному прагненні самому виконувати роль сімейного психотерапевта, неважливості зовнішньої привабливості партнера по шлюбу, занижених потребах інтимно-сексуальних рольових очікувань, значному прагненні до спільної діяльності, негативному ставленні до розлучень.

Вище зазначалося, що шлюбно-сімейна установка $\epsilon$ механізмом формування сімейних стосунків, на яку своєю чергою можна позитивно впливати. Такий вплив, на нашу думку, можна здійснювати в процесі проведення тренінгів, консультацій та інших технік формування шлюбно-сімейних установок. У розробці зазначених технологій ми вбачаємо перспективи наших подальших досліджень.

\section{Список літератури:}

1. Алешина Ю.Е., Гозман Л.Я., Дубовская Е.М. Социально-психологические методы исследования супружескых отношеный. Москва : Москва : Изд-во Моск. Унив-та, 1987. С. 78-90.

2. Олифирович Н.И., Зинкевич-Куземкина Т.А., Велента Т.Ф. Психология семейных кризисов. СанктПетербург : Речь, 2006. С. 184-194.

3. Психодиагностические методики изучения гендерных особенностей личности : метод. рекомендации для студентов, обуч. по специальностям 1-86 0101 «Социальная работа (по направлениям)» и 1-23 0104 «Психология» / сост. Е.Д. Беспанская-Павленко. Минск : БГУ, 2013. 


\section{Panchenko V.O. PSYCHOLOGICAL FEATURES OF MARRIAGE AND FAMILY ATTITUDES OF STUDENT YOUTH}

The relevance of the study of marital and family attitudes and their features in student youth are substantiated in the article.

An experimental study of marriage and family attitudes of student youth of three groups with different areas of educational activity: psychologists, musicians and historians was made. The vector of the research was aimed at: studying gender attitudes of the individual; clarification of the couple's ideas about the importance of sexual relations in family life, personal community of husband and wife, parental responsibilities, professional interests of each spouse, economic and domestic aspect of the relationship, moral and emotional support, external attractiveness of the partner; determining the attitudes of spouses in relation to the most important spheres of human life in family interaction and to study the degree of socio-psychological compatibility of marriage partners.

The psychological features of marriage and family attitudes of student youth were determined. Representatives of all groups prefer the settings of support, gravity and independence. Psychology students expect their parents to take an active parental position in the future; they want to "be a psychologist" in their own family, and this is due to the specifics of their education; feel emotional support from a partner; want to connect life with an outwardly attractive person; they are loyal to divorces.

Music students have high scores on the scale of personal identification; strive to meet their own professional needs; seek to see a partner as an emotional leader; have a significant attitude to their own attractiveness; need to realize themselves in the professional sphere, do not attach importance to household problems.

The peculiarity of the attitudes of students-historians is as follows: the desire to give the rights of an emotional leader to their own partner while seeking to perform the role of family psychotherapist; the insignificance of the external attractiveness of the marriage partner; underestimated needs of intimate-sexual role expectations; significant desire for joint activities; negative attitude to divorce.

Prospects for further scientific research within this topic were outlined.

Key words: family, marriage, marital and family attitudes, gender attitudes, expectations in marriage, student youth. 